\title{
DNA vaccine-mediated innate immune response triggered by PRRs in teleosts
}

\author{
Takashi Aoki · Tomokazu Takano $\cdot$ Jun-ichi Hikima
}

Received: 6 November 2014 / Accepted: 10 December 2014 / Published online: 10 January 2015

(C) The Author(s) 2015. This article is published with open access at Springerlink.com

\begin{abstract}
Aquacultured fish are threatened by many pathogens, often with serious consequences. Vaccination is one of the most effective tools for enhancing host immunity and protecting fish from infections. Vaccination with DNA vaccine is based on the administration of the gene encoding a vaccine antigen. Several effective DNA vaccines that encode viral or bacterial antigenic proteins have already been shown to be effective for cultured fish. This review summarizes current knowledge on fish DNA vaccines, and the mechanism of interaction between the DNA vaccines and host immunity, especially focusing on the enhancement of innate immunity mediated through direct-recognition of DNA vaccine by pattern recognition receptors (PRRs). To date, numerous fish PRR genes have been identified, and the primordial functions of PRRs involved in the innate immune response to viral and bacterial nucleic acids have been increasingly clarified. The evolutionary conservations and divergences in the PRR mechanisms of teleosts and
\end{abstract}

This article publication is sponsored by the Japan Society for the Promotion of Science (JSPS) in a Grant-in-Aid for Publication of Scientific Research Results (KAKENHI 262003).

\section{T. Aoki $(\square)$}

Institute for Nanoscience and Nanotechnology, Waseda

University Center for Advanced Biomedical Sciences (TWIns),

2-2 Wakamatsu-cho, Shinjuku-ku, Tokyo 162-8480, Japan

e-mail: aokitaka@aoni.waseda.jp

\section{T. Takano}

Aquatic Animal Health Division, National Research Institute of Aquaculture, Fisheries Research Agency, 422-1

Nakatsuhamaura, Minami-ise, Mie 516-0193, Japan

\section{J. Hikima}

Department of Biochemistry and Applied Biosciences, Faculty of Agriculture, University of Miyazaki, 1-1 Gakuen

Kibanadai-nishi, Miyazaki 889-2192, Japan mammals are focused on their molecular features and the recognition of DNA vaccine mediated by TANK binding kinase 1 . In addition, the mechanism of type I interferon production in teleosts, which is enhanced after the recognition of cytosolic nucleic acids and current topics on DNA sensing by PRRs are also introduced.

Keywords DNA vaccine $\cdot$ Innate immunity $\cdot$ Pattern recognition receptors (PRRs) · Nucleic acid sensing · Type I interferon (IFN)

\section{Immune response activated through DNA vaccine}

DNA vaccine against fish pathogens

Live, weakened, or killed bacterial pathogens, which were the first generation vaccines, are composed of whole pathogens. Bacterins are killed pathogenic bacteria that induce the humoral immune response such as the production of neutralizing antibodies. Vaccines made from live (or attenuated) pathogens can stimulate both cellular and humoral immune responses. Both types of vaccine are currently used in aquaculture [1, 2]. Second generation vaccines consist of antigenic subunits from the pathogen. These vaccines, called subunit vaccines, elicit humoral immune responses, such as production of neutralizing antibodies, but not cellular immune responses. Third generation vaccines or DNA vaccines are directly inoculated plasmid DNAs that encode a specific protective antigen gene under the control of a eukaryotic promoter. In mammals, once the plasmid DNA is administered in vivo, the encoded antigen is thought to be expressed in the host cells. At this point, antigen-presenting cells, such as dendritic cells, take up the antigen, process it and elicit the production of neutralizing antibodies, helper 
Table 1 DNA vaccine studies on viral and bacterial pathogens in fish

\begin{tabular}{|c|c|c|c|c|}
\hline Pathogens & Antigen gene inserted & Host & Route & References \\
\hline \multicolumn{5}{|l|}{ RNA viruses } \\
\hline $\begin{array}{l}\text { Atlantic halibut nodavirus } \\
(\text { AHNV) }\end{array}$ & Coat protein & $\begin{array}{l}\text { Turbot (Scophthalmus } \\
\text { maximus) }\end{array}$ & Intramuscular (i.m.) & [118] \\
\hline \multicolumn{2}{|c|}{$\begin{array}{l}\text { Infectious hematopoietic necro- Glycoprotein } \\
\text { sis virus (IHNV) }\end{array}$} & $\begin{array}{l}\text { Rainbow trout (Oncorhynchus } \\
\text { mykiss) }\end{array}$ & i.m. & {$[4]$} \\
\hline & Nucleocapsid protein & Rainbow trout & i.m. & [4] \\
\hline \multirow{2}{*}{$\begin{array}{l}\text { Infectious pancreatic necrosis } \\
\text { virus (IPNV) }\end{array}$} & Polyprotein plus VP2 & Atlantic salmon (Salmo salar) & i.m. & [119] \\
\hline & VP2 & Rainbow trout & Oral (with microspheres) & [11] \\
\hline \multirow{2}{*}{$\begin{array}{l}\text { Infectious salmon anaemia } \\
\text { virus (ISAV) }\end{array}$} & Hemagglutinin-esterase & Atlantic salmon & i.m. & {$[120]$} \\
\hline & Nucleoprotein & Atlantic salmon & i.m. & {$[120]$} \\
\hline \multirow[t]{2}{*}{ Hirame rhabdovirus (HIRRV) } & Glycoprotein & Japanese flounder & i.m. & {$[10,22]$} \\
\hline & Nucleocapsid protein & Japanese flounder & i.m. & [22] \\
\hline \multirow{2}{*}{$\begin{array}{l}\text { Spring viraemia of carp virus } \\
\text { (SVCV) }\end{array}$} & Glycoprotein & Common carp & i.m. & [13] \\
\hline & & $\begin{array}{l}\text { Koi (Cyprinus carpio haema- } \\
\text { topterus) }\end{array}$ & i.m. & {$[121]$} \\
\hline \multirow{2}{*}{\multicolumn{2}{|c|}{$\begin{array}{l}\text { Viral haemorrhagic septicaemia Glycoprotein } \\
\text { virus (VHSV) }\end{array}$}} & Rainbow trout & i.m. & {$[5,122]$} \\
\hline & & Japanese flounder & i.m. & [20] \\
\hline VHSV and IHNV (cocktail) & Glycoproteins & Rainbow trout & i.m. & [123] \\
\hline \multicolumn{5}{|l|}{ DNA viruses } \\
\hline $\begin{array}{l}\text { Channel catfish herpesvirus } \\
\text { (CCHV) }\end{array}$ & ORF 59 plus ORF 6 & $\begin{array}{l}\text { Channel catfish (Ictalurus } \\
\text { punctatus) }\end{array}$ & i.m. & {$[124]$} \\
\hline $\begin{array}{l}\text { Lymphocystis disease virus } \\
\text { (LCDV) }\end{array}$ & Major capsid protein & Japanese flounder & $\begin{array}{l}\text { Oral (with PLGA } \\
\text { nanoparticles) }\end{array}$ & [125] \\
\hline Koi herpesvirus (KHV) & ORF25 (glycosilated protein) & Koi & i.m. & {$[126]$} \\
\hline Red seabream iridovirus (RSIV) & Major capsid protein & Red sea bream (Pagrus major) & i.m. & {$[12]$} \\
\hline \multicolumn{5}{|c|}{ Bacteria } \\
\hline Aeromonas veronii & Omp38 and Omp48 & $\begin{array}{l}\text { Spotted sand bass (Paralabrax } \\
\text { maculatofasciatus) }\end{array}$ & i.m. & [127] \\
\hline \multirow[t]{3}{*}{ Edwardsiella tarda } & Eta6 & Japanese flounder & i.m. & {$[14]$} \\
\hline & D15-like surface antigen & Japanese flounder & i.m. & [16] \\
\hline & Eta2 & Japanese flounder & i.m. & {$[15]$} \\
\hline Flavobacterium psychrophilum & Hsp60 and 70 & Rainbow trout & i.m. & {$[128]$} \\
\hline Mycobacterium marinum & Ag85A & $\begin{array}{l}\text { Hybrid striped bass (Morone } \\
\text { saxatilis } \times \text { M. chrysops) }\end{array}$ & i.m. & {$[17,18]$} \\
\hline Streptococcus agalactiae & Surface immunogenic protein & $\begin{array}{l}\text { Nile tilapia (Oreochromis } \\
\text { niloticus) }\end{array}$ & $\begin{array}{l}\text { Oral (with recombinant } \\
\text { bacteria) }\end{array}$ & [129] \\
\hline S. iniae & Secretory antigen Sia10 & Turbot & i.m. & {$[130]$} \\
\hline Vibrio alginolyticus & OmpW & $\begin{array}{l}\text { Crimson snapper (Lutjanus } \\
\text { erythropterus) }\end{array}$ & i.m. & {$[131]$} \\
\hline V. anguillarum & $\begin{array}{l}\text { 38-kDa major outer membrane } \\
\text { prion protein }\end{array}$ & Asian seabass (Lates calcarifer) & i.m. & [132] \\
\hline V. harveyi & DegQ and Vhp1 & Japanese flounder & i.m. & [133] \\
\hline S. iniae and $V$. anguillarum & Sia10 and OmpU & Japanese flounder & i.m. & [134] \\
\hline
\end{tabular}

$\mathrm{T}$ cells, and cytotoxic $\mathrm{T}$ lymphocytes (CTLs). This immune cascade results in the elimination of intracellular pathogens, and is a unique feature of DNA vaccines. Many studies have investigated DNA vaccines against fish pathogens, especially viruses and intracellular bacteria [2, 3] (Table 1). DNA vaccines against rhabdoviruses, such as infectious hematopoitic necrosis virus (IHNV), viral haemorrhagic septicaemia virus (VHSV), have been most successful [4, 5]. A DNA vaccine against IHNV has been approved for use in Canada [6]. The glycoprotein (G-protein) genes are highly immunogenic and are often utilized to develop DNA vaccines against rhabdoviruses. All that is needed is an 
intramuscular (i.m.) injection of purified plasmid DNA. In rainbow trout fingerlings, nanogram levels of plasmid DNA are enough to induce protective immunity against IHNV and VHSV [7-9]. DNA vaccines have been found to be effective against hirame rhabdovirus (HIRRV) [10], infectious pancreatic necrosis virus (IPNV) [11], red seabream iridovirus (RSIV) [12], and spring viraemia of carp virus (SVCV) [13]. They may also be useful against intracellular bacterial pathogens, including Edwardsiella tarda [5, 1416] and Mycobacterium marinum [17, 18].

Transcriptomic analysis of DNA vaccine-inoculated fish and the expected immune responses

We have previously analyzed the expression of Japanese flounder Paralichthys olivaceus genes in DNA vaccineinoculated fish using DNA microarray [19-23].

The genes involving lymphocyte activation, such as CD20, CD40 and B lymphocyte cell adhesion molecules were up-regulated at 1 and 3 days post-immunization with VHSV G-protein gene [20, 21]. Homologs of mammalian $\mathrm{T}$ cell activation-related molecules (such as cytohesin-1, CXCR3, CARD11/CARMA1, gp96, CaMKII, DAP10, DC-SIGN, PA28 $\alpha$ and $\alpha 2 \mathrm{~m}$ ) were also up-regulated in Japanese flounder immunized with HIRRV G-protein gene [23]. Up-regulation of these genes may suggest that HIRRV G-protein gene induces B cell activity and antigenspecific humoral immunity. Inoculation of fish with G-protein genes of VHSV and IHNV induced the production of neutralizing antibodies which may have helped to protect against these viruses [24-26]. Hence, B cells activated by DNA vaccination against VHSV G-protein gene might play an important role in the immune response [27].

On the other hand, DNA vaccination against rhabdovirus provided high levels of specific protection without producing detectable amounts of neutralizing antibodies [5, 28]. A cDNA microarray analysis of Japanese flounder immunized with DNA vaccines encoding rhabdovirus G-proteins showed up-regulation of the genes that were involved in cellular immune responses, such as the CD8 $\alpha$ chain gene [20-23]. The role of cellular immunity in the DNA vaccine-inoculated fish has not yet been clarified. However, Somamoto et al. [29, 30] reported a specific cell-mediated immune response of crucian carp lymphocytes to the MHC-matched cells infected with crucian carp hematopoietic necrosis virus. Further, $\mathrm{CD} 8^{+}$cytotoxic $\mathrm{T}$ cells (CTLs) were considered to be involved in the antiviral adaptive immunity of the carp [30]. Taken together, $\mathrm{CD}^{+}$CTLs of teleosts may also have a role in the specific protection provided by DNA vaccination.

In addition to inducing antigen-specific immune responses, DNA vaccination also induces non-specific innate immune responses. Vaccination of rainbow trout with the G-protein gene from IHNV induced early antiviral defense against a VHSV challenge, suggesting that DNA vaccination is also involved in the activation of the innate immune system [31]. Using a Japanese flounder cDNA microarray, we detected an immediate up-regulation of non-specific immune response genes, including NK Kupffer cell receptors, MIP1-a, and antiviral Mx1 protein (Mx1), following administration of VHSV G-protein genes [20, 21]. Furthermore, the interferon-stimulated gene $15 \mathrm{kDa}$ (ISG15), ISG56, and Mx1 were strongly induced after the vaccination with the HIRRV G-protein gene [22, 23]. Mx1, ISG15, and ISG56 are known as type I interferon (IFN)-inducible genes, which inhibit viral replication and protein synthesis [32-36]. Interestingly, these type I IFNinducible genes were induced by the protective HIRRV G-protein immunization but not by the inefficient nucleocapsid (N) protein immunization [22]. Similarly, type I IFN-related genes were up-regulated at systemic sites (e.g., gills, kidney, and spleen) by the IHNV G-protein gene in rainbow trout. Taken together, these findings indicate that induction of the type I IFN system across multiple tissues may be one of the major functions of early anti-viral innate immunity in DNA-vaccinated fish [37].

Although the innate immune system provides an early defense against infection, it has been considered to act as a temporary system until adaptive immune responses can be triggered. However, from the recent studies in mammals, it is currently believed that activation of innate immunity is a prerequisite for induction of acquired immunity [38]. For a DNA vaccine to induce an effective immune response against fish pathogenic viruses, there must be both a type I IFN-mediated innate immune response and an adaptive immune response (Fig. 1). Type-I IFN systems in teleosts are distinct from those in mammals, because teleost species have had a long and complex genome history and have developed a specific adaptation to the aquatic environment [39]. Hence, uncovering the mechanism for induction of the type I IFN system following DNA vaccination of teleosts is a subject of great interest. In the next section, we summarize the present knowledge regarding the molecules involved in recognition of a DNA vaccine and activation of IFNs in teleosts.

\section{The immune responses activated by nucleic acid recognition}

Pattern recognition receptors (PRRs) involved in nucleic acid recognition in teleosts

In mammals, the innate immune response is initiated through the recognition of pathogen-associated molecular patterns (PAMPs) by pattern recognition receptors 
Fig. 1 Schematic overview of type 1 IFN-mediated immune responses in DNA vaccine inoculated fish. Type I IFN activates both innate and adaptive immunity to modulate an effective system to eliminate intracellular pathogens. $C T L$ cytotoxic T lymphocyte, IFN interferon, $I F N R$ interferon receptor, $M H C$ major histocompatibility complex, TCR T-cell receptor

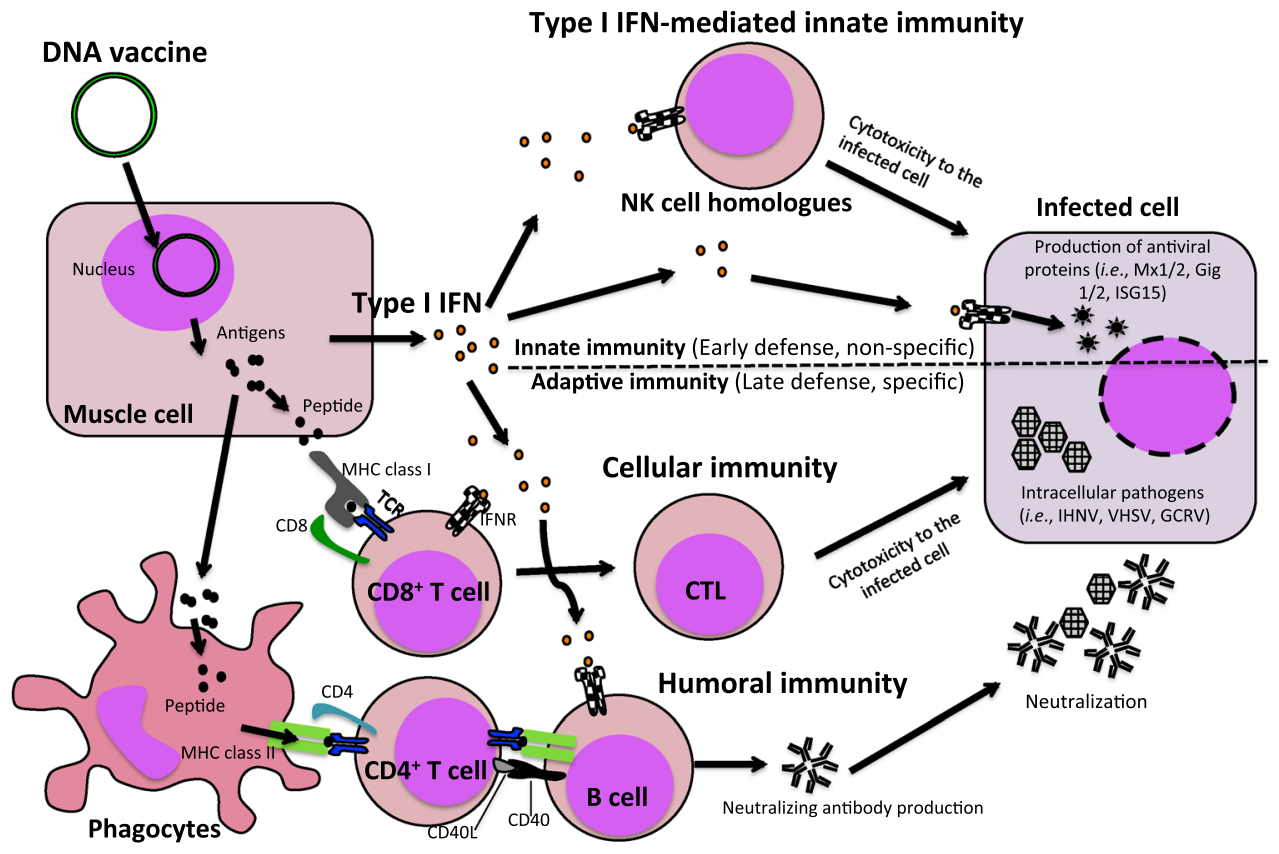

(PRRs). The signaling PRRs include the Toll-like receptors (TLRs), retinoic acid inducible gene (RIG)-I-like receptors (RLRs), and nucleotide-oligomerization domain (NOD)-like receptors (NLRs). The DNA of the vaccine is directly recognized by some of these receptors, which then trigger innate immune responses [2, 3, 40]. These receptors include CpG DNA sensors (e.g., TLR9), B-form DNA sensors (e.g., Z-DNA binding protein-1; ZBP), and inflammasomes. ZBP is also known as DAI (DNAdependent activator of IFN-regulatory factors). Inflammasomes include NACHT-, leucine-rich repeat (LRR)-, and pyrin domain (PYD)-containing proteins (NALP3). For example, DNA vaccines containing human-specific $\mathrm{CpG}$ motifs induced the maturation of human monocytes, suggesting that improvements to plasmid DNA for innate immune signaling activation are important for the enhancement of immunogenicity and induction of optimal immune responses [41, 42]. In teleosts, six TLRs and three RLRs have been demonstrated to recognize nucleic acids (Table 2), while NLR members which are responsible for exogenous nucleotide recognition have not been identified except for AIM2 described in the section after next, "Other current topics on cytosolic DNA sensors (CDSs)". In teleosts, PRR-associated sensing of exogenous nucleotides has been shown to lead to antiviral responses via the production of type I IFN and other cytokines. Hence, exogenous nucleic acids (i.e., DNA vaccines, viral RNA, and bacterial DNA) and their analogs can be used as vaccine adjuvants for aquaculture [43]. In this section, therefore, we summarize the nucleotide-sensing PRRs and their cascades in teleosts.
Nucleic acid-sensing TLRs in teleosts

TLRs are homologues of the Drosophila Toll receptor. The latter was initially identified as a receptor essential for dorsoventral polarity during development, and was shown to participate in the innate immune responses against fungal infections [44]. In mammals, TLRs are widely distributed on the cell surface and on the endosomal membrane of immune cells, including macrophages, dendritic cells (DCs), B cells, and specific types of $\mathrm{T}$ cells. Both fibroblasts and epithelial cells, which are non-immune cells, also express TLRs [45, 46]. TLRs are type- 1 trans-membrane glycoproteins, which comprise an N-terminal extracellular leucine-rich repeat (LRR) domain and a C-terminal intracellular Toll/IL-1 receptor (TIR) domain. The LRR domain is responsible for the recognition of ligands specific to a particular PAMP [47]. These structural characteristics are conserved in vertebrate TLRs, except the soluble form of TLRs (e.g., TLR5S in teleosts) [48, 49]. Several teleost TLRs (TLR3, -7, -8, -9, -21 and -22) may be able to sense nucleic acids [50].

TLR3 is an endosomal membrane receptor that recognizes pathogen-derived double-stranded RNAs (dsRNAs), such as dsRNA virus genomes. The dsRNA analog poly I:C has often been used as an antiviral immune response mediator in teleosts. Injection of poly I:C into Atlantic salmon resulted in the production of type I IFN and expression of antiviral Mx gene in immune-related tissues [51]. In addition, in human embryonic kidney (HEK) 293 cells expressing Japanese puffer TLR3 and rainbow trout gonadal (RTG)-2 cells, poly I:C stimulation was found to activate the IFN gene promoter [52]. 
Table 2 Research reports on nucleic acid sensing-PRRs in teleosts which demonstrated the functional involvement of the receptors to type I IFN and antiviral activity

\begin{tabular}{|c|c|c|c|c|}
\hline PRRs & Ligands & Fish & Functional characteristics demonstrated in the report & References \\
\hline \multicolumn{5}{|l|}{ TLRs } \\
\hline \multirow[t]{3}{*}{ TLR3 } & \multirow[t]{3}{*}{ dsRNA, poly I:C } & Japanese flounder & \multicolumn{2}{|l|}{$\begin{array}{l}\text { Poly I:C stimulation of JfTLR3-overexpressing cells signifi-[135] } \\
\text { cantly induced IFN-inducible gene and NF- } \mathrm{B} \text { B reporter } \\
\text { activity }\end{array}$} \\
\hline & & Rare minnow (Gobiocypris rarus) & $\begin{array}{l}\text { TLR3-mediated Mx expression was confirmed by using } \\
\text { RNAi and transgenic techniques }\end{array}$ & [136] \\
\hline & & Japanese pufferfish & $\begin{array}{l}\text { TLR3 resides in endoplasmic reticulum and recognizes } \\
\text { relatively short-sized dsRNA }\end{array}$ & {$[52]$} \\
\hline \multirow[t]{2}{*}{ TLR7 } & \multicolumn{2}{|c|}{ ssRNA, imidazoquinolineAtlantic salmon } & $\begin{array}{l}\text { TLR7 gene expression was to type I IFN and IFN } \gamma \text { treat- } \\
\text { ment in primary head kidney cells. } \\
\text { IFNb and IFNc are the main IFNs induced through the } \\
\text { TLR7 pathway because R848, an ssRNA analog, induced } \\
\text { high transcript levels of IFNb and IFNc in the head kidney } \\
\text { and spleen }\end{array}$ & {$[137,138]$} \\
\hline & & Rainbow trout & $\begin{array}{l}\text { Rainbow trout anterior kidney leukocytes produced elevated } \\
\text { levels of pro-inflammatory and type I IFN cytokine } \\
\text { mRNA in response to stimulation with the human TLR7/8 } \\
\text { agonist R848 }\end{array}$ & \\
\hline \multirow[t]{2}{*}{ TLR8 } & \multicolumn{2}{|c|}{ ssRNA, imidazoquinolineAtlantic salmon } & $\begin{array}{l}\text { Promoter analysis predicted several transcription factor } \\
\text { binding sites in the TLR8a1/2 and TLR8b1 5' flanking } \\
\text { regions, namely C/EBP, AP-1, STAT, NFKB, and IRF fam- } \\
\text { ily, suggesting cytokine regulation of the genes. } \\
\text { TLR8a1 gene expression was sensitive to type I IFN and } \\
\text { IFN } \gamma \text { treatment in salmon head kidney-1 cells }\end{array}$ & {$[137]$} \\
\hline & & Rainbow trout & $\begin{array}{l}\text { Two TLR8 genes exist (TLR8a1 and TLR8a2) in rainbow } \\
\text { trout. } \\
\text { Rainbow trout anterior kidney leukocytes produced elevated } \\
\text { levels of pro-inflammatory and type I IFN cytokine } \\
\text { mRNA in response to stimulation with the human TLR7/8 } \\
\text { agonist R848 }\end{array}$ & [139] \\
\hline \multirow[t]{2}{*}{ TLR9 } & \multirow[t]{2}{*}{ CpG-ODN } & Atlantic salmon & $\begin{array}{l}\text { Atlantic salmon TLR9 has been found to interact with } \\
\text { synthetic oligonucleotides via a CpG-independent but a } \\
\text { pH-dependent mechanism. } \\
\text { When overexpressed in salmonid cell lines, the salmon } \\
\text { TLR9 spontaneously activates ISRE-containing promoters } \\
\text { of genes involved in the IFN response }\end{array}$ & {$[140,141]$} \\
\hline & & Japanese flounder & $\begin{array}{l}\text { The flounder tumor necrosis factor (TNF) gene promoter } \\
\text { was activated in TLR9-transformed hirame natural } \\
\text { embryo (HINAE) cells upon stimulation with synthesized } \\
\text { CpG oligodeoxynucleotide (ODN). } \\
\text { When the expression of the flounder TLR9 was knocked } \\
\text { down in vivo by small interfering RNA, CpG ODN- } \\
\text { mediated immune response and antiviral activity were } \\
\text { significantly blocked }\end{array}$ & {$[59,60]$} \\
\hline TLR21 & CpG-ODN & Zebrafish & $\begin{array}{l}\text { Results from cell-based activation assays indicate that } \\
\text { zebrafish TLR } 21 \text { is functional, responding to CpG-ODN } \\
\text { but not to other TLR ligands. } \\
\text { TLR } 21 \text { responded preferentially to CpG-ODN with } \\
\text { GTCGTT motifs. } \\
\text { TLR9 and TLR } 21 \text { of zebrafish cooperatively mediate the } \\
\text { antimicrobial activities of CpG-ODN }\end{array}$ & {$[66]$} \\
\hline TLR22 & Long-sized dsRNA & Japanese pufferfish & $\begin{array}{l}\text { TLR22 recognizes long-sized dsRNA on the cell surface. } \\
\text { When fish cells expressing TLR22 are exposed to dsRNA } \\
\text { or aquatic dsRNA viruses, cells induce IFN responses to } \\
\text { acquire resistance to virus infection }\end{array}$ & {$[52]$} \\
\hline
\end{tabular}


Table 2 continued

\begin{tabular}{|c|c|c|c|c|}
\hline PRRs & Ligands & Fish & Functional characteristics demonstrated in the report & References \\
\hline \multicolumn{5}{|l|}{ RLRs } \\
\hline \multirow[t]{2}{*}{ RIG-I } & \multicolumn{2}{|c|}{ Viral RNA, 5'ppp-dsRNAEPC cells } & $\begin{array}{l}\text { N-terminal of RIG-I led to a strong induction of both IFN } \\
\text { and ISGs, conferring on fish cells protection against VHS } \\
\text { infection }\end{array}$ & {$[142]$} \\
\hline & & Grass carp & $\begin{array}{l}\text { Overexpression of RIG-I decreased the viral titer of GCRV } \\
\text { in CIK cells. } \\
\text { IFN production was significantly increased in RIG- } 1 \text { gene } \\
\text { transfected cells following GCRV infection }\end{array}$ & [86] \\
\hline \multirow[t]{2}{*}{ MDA5 } & Viral RNA, poly I:C & Japanese flounder & $\begin{array}{l}\text { HINAE cells overexpressing MDA5 showed a lower cyto- } \\
\text { pathic effect (CPE) against VHSV, hirame rhabdovirus } \\
\text { (HIRRV) and infectious pancreatic necrosis virus (IPNV) } \\
\text { infection }\end{array}$ & [70] \\
\hline & & Zebrafish & $\begin{array}{l}\text { Gene expression of zebrafish MDA5 genes are induced by } \\
\text { SVCV and Edwardsiella tarda infection. } \\
\text { Overexpression of MDA5 genes in fish cells resulted in } \\
\text { significant induction of type I IFN promoter activity and } \\
\text { enabled the protection of transfected cells against SVCV } \\
\text { infection }\end{array}$ & [143] \\
\hline \multirow[t]{2}{*}{ LGP2 } & Viral RNA, poly I:C & Japanese flounder & $\begin{array}{l}\text { The expression of LGP } 2 \text { mRNA increased after VHSV } \\
\text { infection and poly I:C stimulation. } \\
\text { Type I IFN and IFN-inducible genes (Mx and ISG15) in } \\
\text { HINAE cells overexpressing LGP2 were increased by } \\
\text { poly I:C and viral infections. LGP2 transcriptional control } \\
\text { is crucially involved in regulation by interferon regulatory } \\
\text { factor (IRF) } 3\end{array}$ & {$[69,144]$} \\
\hline & & Rainbow trout & $\begin{array}{l}\text { LGP2 were constitutively produced in fibroblast and mac- } \\
\text { rophage cell lines and upregulated by poly I:C, recombi- } \\
\text { nant IFN, or infection by RNA viruses. } \\
\text { Overexpression of MDA5 and LGP2 resulted in significant } \\
\text { accumulation of Mx transcripts in cultured cells }\end{array}$ & {$[145]$} \\
\hline
\end{tabular}

TLR7, -8 and -9 are also expressed on the endosome membranes. Mammalian TLR7 and -8 recognize synthetic antiviral imidazoquinoline compounds, which mimic single-stranded RNA (ssRNA), such as bacterial RNA and the RNA viral genomes [46, 53-55]. Imidazoquinolines, such as S-27609 and R848, are also efficient immune modulators in teleosts [56-58]. R848 stimulation was found to upregulate the genes for IFN- $\alpha 1$, IL- $1 \beta$, IL- 8 , and two types of tumor necrosis factor in rainbow trout leukocytes [56]. In salmon leukocytes, IFN- $\beta$ genes were strongly up-regulated by $\mathrm{S}-27609$, while IFN- $\alpha$ genes were up-regulated by poly I:C [58]. Hence, it is likely that salmon TLR7 and -8 are responsible for recognizing ssRNA to activate signaling pathways to produce IFN- $\beta$.

TLR9 recognizes the unmethylated CpG DNA motifs present in viral and bacterial genomes, and initiates immune responses through the production of inflammatory cytokines including type I IFN [46]. CpG motifs are also present in the plasmid backbone, and thus act as an intrinsic "built-in adjuvant" for DNA vaccines [42]. CpG oligodeoxynucleotides (ODNs), which mimic unmethylated $\mathrm{CpG}$ DNA, have been used to examine the role of teleost TLR9. In a transgenic Japanese flounder cell line expressing the
TLR9 gene, CpG ODN stimulation was found to activate the tumor necrosis factor (TNF)- $\alpha$ gene promoter [59]. In flounder, knockdown of TLR9 by a small interfering RNA impaired $\mathrm{CpG}$ ODN-mediated immune response and antiviral activity [60]. These studies suggest that teleost TLR9 directly recognizes $\mathrm{CpG}-\mathrm{ODN}$. Among many kinds of $\mathrm{CpG}$ ODNs, CpG ODN 1681 induced the highest level of IFNlike activity in leukocytes of Atlantic salmon Salmo salar [61]. This IFN-like activity may be mediated by type I IFN and Mx protein, because these molecules were produced from Atlantic salmon leukocytes following stimulation with CpG ODN 1681 [62].

Mammals do not appear to have homologs of TLR21 and -22 [63]. Chicken TLR21 was suggested to be a CpG ODN receptor [64]. As the TLR21 genes of teleosts and chicken are similar, teleost TLR21 is also considered to be a CpG motif receptor [63, 65]. In fact, zebrafish Danio rerio TLR21 responded preferentially to $\mathrm{CpG-ODN}$ with GTCGTT motifs to exhibit antimicrobial activity [66]. Japanese puffer TLR22 was found to recognize longer dsRNAs on the cell surface, whereas tiger puffer TLR3 was found to recognize shorter dsRNAs in the endoplasmic reticulum [52]. Production of IFN was significantly up-regulated 
when Japanese puffer Takifugu rubripes TLR22-expressing RTG-2 cells were exposed to dsRNA genome of IPNV, and the stimulated cells showed an increased resistance to IPNV infection [52].

Retinoic acid inducible gene (RIG)-I-like receptors (RLRs) in teleosts

The RLR family consists of three members: RIG-I which is also called DEAD box poly peptide 58 (DDX58); melanoma differentiation-associated gene 5 (MDA5), which is also called IFN induced with helicase $\mathrm{C}$ domain 1 (IFIN1); and laboratory of genetics and physiology 2 (LGP2), which is also called DExH box polypeptide 58 (DHX58) [46, 67, 68]. Teleost and mammalian RLRs have a number of structural similarities [65]. In teleosts, the RIG-I, MDA5 and LGP2 genes are expressed in most tissues and cell lines [65, 69-71]. The expression levels of the fish RLR mRNAs were increased in various tissues upon infection by several viruses, such as SVCV, grass carp Ctenopharyngodon idellus reovirus (GCRV) and IPNV [72-79].

In mammals, RLRs sense cytoplasmic viral ssRNAs and dsRNAs. Mammalian RIG-I is capable of recognizing $5^{\prime}$-triphosphate (5'ppp)-capped ssRNA and dsRNA (both capped and uncapped) [80-82], including poly I:C and viral dsRNAs generated by viral replication [82-84]. In contrast, MDA5 senses only long dsRNA containing both poly I:C and viral RNA [83]. LGP2 recognizes dsRNAs and 5'ppp-ssRNA [85].

In teleosts, overexpression of grass carp RIG-I enhanced type I IFN gene expression, and decreased the titer of grass carp reovirus (GCRV) to about the titer in grass carp kidney cells [86]. Further, the gene expression level of Mx2 was significantly higher in the grass carp RIG-I-transfected cells following GCRV infection or poly I:C stimulation than in the normal cells [86]. GCRV-induced gene 1 (Gig1), which is unique to fish species, was significantly induced by intracellular poly I:C through the IFN signaling pathway triggered by RIG-I-like receptors. Overexpression of the Gig1 gene in a crucian carp Carassius auratus blastulae embryonic (CAB) cell line resulted in a significant reduction of GCRV titers [87]. Similarly, in vitro antiviral activity against SVCV was potentiated in Gig2 (Drel) gene-transfected epithelioma papulosum cyprinid (EPC) cells [88]. Rapid production of Gig protein in response to poly I:C transfection in $\mathrm{CAB}$ cells were determined by immunofluorescence microscopy. The rapid and abundant expression helps Gig1 to quickly exert its antiviral effects when host cells respond to virus infection [87]. These finding suggest that the RIG-I system also plays a crucial role in antiviral activity in teleosts. We also demonstrated the involvement of RLRs in virus recognition and antiviral response in Japanese flounder. Hirame (Japanese flounder) natural embryo (HINAE) cells overexpressing MDA5 showed a decreased cytopathic effect (CPE) against VHSV, HIRRV and IPNV infection. When infected with VHSV, MDA5-overexpressing HINAE cells had significantly lower virus titer than normal HINAE cells [70]. Similarly, the CPEs of the viruses were delayed by the overexpression of Japanese flounder LGP2 in HINAE cells. Furthermore, mRNA expression levels of type I IFN and IFN-inducible genes (Mx and ISG15) in the LGP2-overexpressing cells were increased by poly I:C stimulation and viral infections [69]. These results suggest that teleost RLRs have roles in the recognition of ssRNA and dsRNA to induce the production of type I IFN and IFN-related antiviral proteins.

Signaling cascades for type I IFN production result from the nucleic acid-sensing PRRs in teleosts

The signaling pathways of TLRs are mediated by selective usage of adaptor molecules, MyD88, TRIF, TIRAP and TRAM [38].

On poly I:C-stimulated fish cells, Japanese puffer fish TLR3 and -22 recruit the TRIF adaptor protein (synonymous with Toll-IL-1-receptor-containing adaptor molecule-1; TICAM-1), which in turn moves from the TLR to a cytoplasmic signalosome region [52]. Thus, the TRIF is thought to act as a shuttling platform for IFN signaling via fish TLR3 and -22 [52]. In addition, the luciferase reporter assays have demonstrated that TRIFs of zebrafish and pufferfish activate type I IFNs [52, 89, 90].

Mammalian TLR7, -8, and -9-dependent production of type I IFN requires direct interaction of MyD88 and IRF7 [38]. In teleosts, although the TLR7 and -8 genes have also been identified, their roles and associated signaling molecules have not been elucidated. Mammalian TLR9 interacts with the TIR domain of MyD88 through a BB loop in the box 2 region of its cytosolic TIR domain, and this box region is also conserved in zebrafish TLR9 [66]. Mutation of residues in the box 2 abrogated activation of zebrafish TLR9 by CpG-ODNs [66]. Hence, zebrafish TLR9 is structurally and functionally similar to the mammalian TLR9, suggesting that zebrafish TLR9 relates to the MyD88dependent signaling pathway. Cytosolic RLR-mediated signaling pathway also induces the production of type-I IFN in teleosts as mentioned above. The details of TANKbinding kinase 1 mediated type-I IFN production pathways are introduced in the next section.

\section{The key kinase for DNA recognition, TANK-binding kinase 1 (TBK1)}

In the recognition of double stranded DNA (dsDNA) in mammals, DNA vaccine-induced immunogenicity is 
Fig. 2 Schematic diagram of the expected intracellular signaling pathways following DNA vaccination in fish. TLR9 and -21 recognize $\mathrm{CpG}$ motifs of DNA vaccine in the endosome, and then the MyD88-dependent pathway is activated. Cytosolic DNA sensors detect DNA vaccine in the cytoplasm to activate IRFs (IRF3 and/or -7) through TBK1. The TBK1-dependent signaling pathway is also important in signal transduction from the RLR families in detecting transcribed antigen mRNA. TLR3, -7 and -8 recognize RNAs in the endosome; however, the transfer of antigen mRNA into the endosome has yet to be elucidated

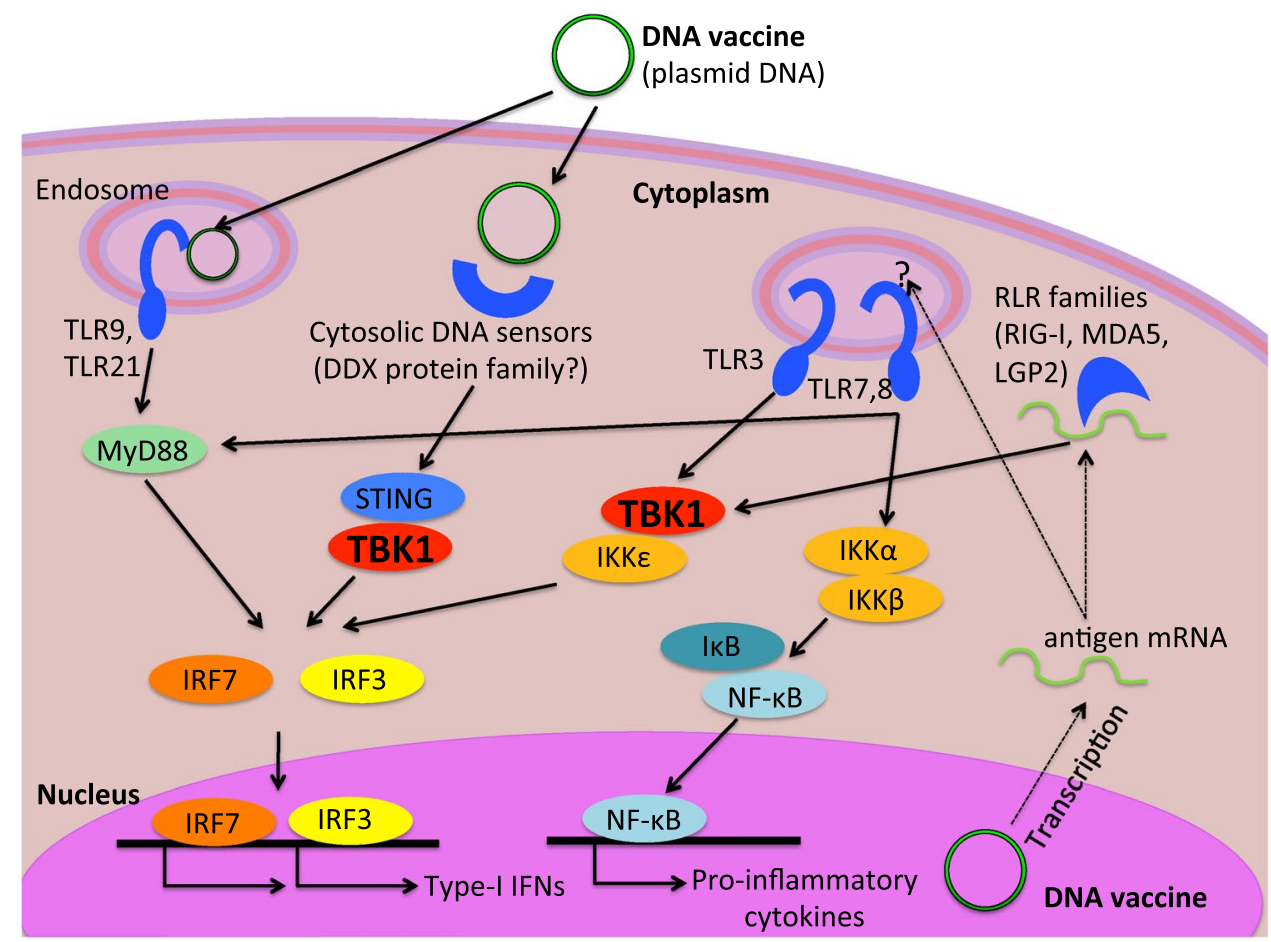

mediated by TANK-binding kinase 1 (TBK1) [92]. TBK1 is also known as NFKB-activating kinase (NAK). Cytoplasmic DNA is recognized by several receptors, including DAI, IFI16, DDX41 and RNA polymerase III [93]. These cytosolic DNA sensors interact with TBK1 through stimulator of IFN genes (STING), which act as adaptors in the type-I IFN production pathway [94]. This suggests that the cytosolic DNA sensors could sense a DNA vaccine and induce the antiviral responses.

In the TLR3 and RLR pathways, type-I IFN production is triggered by the phosphorylation of IRF3 and -7 by TBK1 or inducible IкB kinase epsilon (IKK $\varepsilon$ ) [91, 95, 96]. IKK $\varepsilon$ (also known as IKK $i$ ) is encoded by the IKBKE gene. In mice, cells that are deficient in both TBK1 and IKK $\varepsilon$ usually fail to produce type-I IFN in response to viral infection [97, 98]. Following activation of TLRs and RLRs by viral nucleic acids, TBK1 and IKK $\varepsilon$ assemble with TNF receptor-associated factor 3 (TRAF3) and TANK to phosphorylate IRF3 and IRF7 at multiple serine and threonine residues [99-102]. The phosphorylation leads to the dimerization and nuclear transfer of IRFs, and also induces the expression of pro-inflammatory and antiviral genes [103, 104].

In general, TBK1 and IKK $\varepsilon$ are known as a related pair of non-canonical IKKs, as they differ from other IKK family members, such as IKK $\alpha$ and IKK $\beta$, in that they function in the upstream of the NF- $\kappa \mathrm{B}$ signal transduction cascade. [105]. Despite the structural similarities of TBK1 and $\mathrm{IKK} \varepsilon$, they exhibit differential gene expression patterns. Similar to IKK $\alpha$ and IKK $\beta$, TBK1 is ubiquitously expressed [106]. In contrast, IKK $\varepsilon$ expression is restricted to particular lymphoid tissues, immune-related cells and various epithelial-derived cell lines [106-109].

In teleosts, TBK1 transcripts have been identified in zebrafish [89], Atlantic cod Gadus morhua [110], common carp Cyprinus carpio [73] and goldfish Carassius auratus [111]. The amino acid sequences corresponding to these transcripts are highly conserved with respect to TBK1s of other vertebrates $[73,112]$. Studies have shown that goldfish TBK1 activates the expression of two type I IFN promoters in a process mediated by IRF3 and -7 [111] while zebrafish TBK1 is capable of interacting with TRIF, which also interacts with TLR3 [89]. In goldfish, activation of IRF3 by TBK1 also has a role in RIG-I- and MDA5-mediated signaling [111]. In fish, STING (stimulator of interferon genes) has a role similar to RLR in mammals. It stimulates type I IFN production and antiviral responses against RNA and DNA viruses. It is also called MITA (mediator of IRF3 activation). STING interacts with IPS-1 in the RLRIFN production pathway [112]. This indicates that teleosts also possess functional TLR and RLR pathways for producing type I IFN and protecting the host against pathogenic viral infection.

From this evidence, teleost TBK1 functionally induces the type-I IFN pathway after recognition of viral nucleic acids (including dsDNAs and RNAs), involving the abovementioned PAMPs receptors. We hypothesize a model of type-I IFN activation pathway induced by DNA vaccine. In this model, teleost TBK1 could be critically important 
for immunogenicity induced by DNA vaccine, since DNA receptors (i.e., TLR9, -21 and other cytosolic DNA sensors) recognize dsDNA of a foreign plasmid vector (DNA vaccine) and RNA sensors (i.e., TLR3, -7, -8 and RLR families) probably sense antigen mRNA expressed from the DNA vaccine (Fig. 2).

\section{Other current topics on cytosolic DNA sensors (CDSs)}

In mammals, the AIM2-like receptor (ALR inflammasome) and DDX41 [DEAD/H helicase (DDX) protein] act as cytosolic DNA sensors [95, 113]. ALR is a pyrin domaincontaining PRR that forms an inflammasome protein complex with an ASC adaptor to recognize viral and bacterial DNAs [113]. However, no counterparts of the AIM2 gene have been found in any fish species.

The DDX protein family comprises RNA and DNA helicases containing a DExD/H-box domain. Mammalian DDX proteins have been reported to be implicated in the regulation of gene induction and are involved in a few other processes including signal transduction pathways, mRNA splicing, and translational regulation. Several DDX proteins are thought to be involved in innate immunity because they have been shown to work as RNA sensors (e.g., RIG-I and MDA5) and signaling molecules (e.g., DDX3) [83, 114]. In mammals, myeloid dendritic cells (mDCs) have a complex of three helicases (DDX1, DDX21 and DHX36) that acts as a sensor of synthetic RNA duplex poly (I:C) in the cytosol and that pairs with the adaptor TRIF to trigger type I IFN responses [115].

Interestingly, in a cell type with limited basal IFI16 expression, DDX41 presents as an initial sensor of cytoplasmic DNA, activating type I IFN and subsequent IFI16 expression, the latter serving is an amplifier of innate immune responses [115]. In addition to the role for DDX41 with STING, DDX41 receptor directly interacts with cyclic dinucleotides (CDNs) and stimulates $\mathrm{CDN}$-induced type I IFN [116]. The relative roles of STING and DDX41 in sensing CDNs are not clear. One possibility is that DDX41, instead of being the initial sensor of DNA and CDNs, may function as a signaling molecule for STING-dependent DNA and CDN responses. Recently, a central role for DDX41 in DNA-induced STING-dependent responses has been confirmed, demonstrating that in both in vitro and in vivo observations, the E3 ubiquitin ligase TRIM21 showed a negative regulator of DNA responses and that TRIM21 targeted DDX41 for degradation [117]. Because of its role in DNA sensing, DDX41, like other nucleic acid PRRs, may have a role in autoimmune regulation. DDX41has not yet been found in teleosts, although the databases show that teleosts have many types of DDX protein family genes. On the whole, the above-described DNA sensors could be related to the DNA vaccine-activated innate immune responses (shown in Fig. 2), as well.

Open Access This article is distributed under the terms of the Creative Commons Attribution License which permits any use, distribution, and reproduction in any medium, provided the original author(s) and the source are credited.

\section{References}

1. Håstein $T$, Gudding $R$, Evensen $O$ (2005) Bacterial vaccines for fish-an update of the current situation worldwide. Dev Biol (Basel) 121:55-74

2. Aoki T, Hikima J, Castillo CSD, Jung TS, Kondo H, Hirono I (2008) Molecular immunity in the interaction between fish and pathogen for DNA vaccine. In: Bondad-Reantaso MG et al (eds) Proceedings of the Seventh Symposium on diseases in Asian Aquaculture VII. Asian Fisheries Society, Fish Health Section, pp 253-267

3. Coban C, Koyama S, Takeshita F, Akira S, Ishii KJ (2008) Molecular and cellular mechanisms of DNA vaccines. Hum Vaccin 4:453-456

4. Anderson ED, Mourich DV, Fahrenkrug SC, LaPatra S, Shepherd J, Leong JA (1996) Genetic immunization of rainbow trout (Oncorhynchus mykiss) against infectious hematopoietic necrosis virus. Mol Mar Biol Biotechnol 5:114-122

5. Lorenzen N, Lorenzen E, Einer-Jensen K, Heppell J, Wu T, Davis HL (1998) Protective immunity to VHS in rainbow trout (Oncorhynchus mykiss, Walbaum) following DNA vaccination. Fish Shellfish Immunol 8:261-270

6. Salonius K, Simard N, Harland R, Ulmer JB (2007) The road to licensure of a DNA vaccine. Curr Opin Investig Drugs 8:635-641

7. Corbeil S, LaPatra SE, Anderson ED, Kurath G (2000) Nanogram quantities of a DNA vaccine protect rainbow trout fry against heterologous strains of infectious hematopoietic necrosis virus. Vaccine 18:2817-2824

8. Lorenzen E, Einer-Jensen K, Martinussen T, LaPatra SE, Lorenzen N (2000) DNA vaccination of rainbow trout against viral hemorrhagic septicemia virus: a dose-response and time-course study. J Aquat Anim Health 12:167-180

9. Lorenzen N, LaPatra SE (2005) DNA vaccines for aquacultured fish. Rev Sci Tech 24:201-213

10. Takano T, Iwahori A, Hirono I, Aoki T (2004) Development of a DNA vaccine against hirame rhabdovirus and analysis of the expression of immune-related genes after vaccination. Fish Shellfish Immunol 17:367-374

11. de las Heras AI, Rodríguez Saint-Jean S, Pérez-Prieto SI (2010) Immunogenic and protective effects of an oral DNA vaccine against infectious pancreatic necrosis virus in fish. Fish Shellfish Immunol 28:562-570

12. Caipang CM, Takano T, Hirono I, Aoki T (2006) Genetic vaccines protect red seabream, Pagrus major, upon challenge with red seabream iridovirus (RSIV). Fish Shellfish Immunol 21:130-138

13. Kanellos T, Sylvester ID, D'Mello F, Howard CR, Mackie A, Dixon PF, Chang KC, Ramstad A, Midtlyng PJ, Russell PH (2006) DNA vaccination can protect Cyprinus carpio against spring viraemia of carp virus. Vaccine 24:4927-4933

14. Jiao XD, Zhang M, Hu YH, Sun L (2009) Construction and evaluation of DNA vaccines encoding Edwardsiella tarda antigens. Vaccine 27:5195-5202

15. Sun Y, Liu CS, Sun L (2011) Comparative study of the immune effect of an Edwardsiella tarda antigen in two forms: subunit vaccine vs DNA vaccine. Vaccine 29:2051-2057 
16. Sun Y, Liu CS, Sun L (2011) Construction and analysis of the immune effect of an Edwardsiella tarda DNA vaccine encoding a D15-like surface antigen. Fish Shellfish Immunol 30:273-279

17. Pasnik DJ, Smith SA (2005) Immunogenic and protective effects of a DNA vaccine for Mycobacterium marinum in fish. Vet Immunol Immunopathol 103:195-206

18. Pasnik DJ, Smith SA (2006) Immune and histopathologic responses of DNA-vaccinated hybrid striped bass Morone saxatilis $\times$ M. chrysops after acute Mycobacterium marinum infection. Dis Aquat Organ 73:33-34

19. Kurobe T, Yasuike M, Kimura T, Hirono I, Aoki T (2005) Expression profiling of immune-related genes from Japanese flounder Paralichthys olivaceus kidney cells using cDNA microarrays. Dev Comp Immunol 29:515-523

20. Byon JY, Ohira T, Hirono I, Aoki T (2005) Use of a cDNA microarray to study immunity against viral hemorrhagic septicemia (VHS) in Japanese flounder (Paralichthys olivaceus) following DNA vaccination. Fish Shellfish Immunol 18:135-147

21. Byon JY, Ohira T, Hirono I, Aoki T (2006) Comparative immune responses in Japanese flounder, Paralichthys olivaceus after vaccination with viral hemorrhagic septicemia virus (VHSV) recombinant glycoprotein and DNA vaccine using a microarray analysis. Vaccine 24:921-930

22. Yasuike M, Kondo H, Hirono I, Aoki T (2007) Difference in Japanese flounder, Paralichthys olivaceus gene expression profile following hirame rhabdovirus (HIRRV) $\mathrm{G}$ and $\mathrm{N}$ protein DNA vaccination. Fish Shellfish Immunol 23:531-541

23. Yasuike M, Kondo H, Hirono I, Aoki T (2011) Gene expression profile of HIRRV $\mathrm{G}$ and $\mathrm{N}$ protein gene vaccinated Japanese flounder, Paralichthys olivaceus during HIRRV infection. Comp Immunol Microbiol Infect Dis 34:103-110

24. Traxler GS, Anderson E, LaPatra SE, Richard J, Shewmaker B, Kurath G (1999) Naked DNA vaccination of Atlantic salmon Salmo salar against IHNV. Dis Aquat Organ 38:183-190

25. McLauchlan PE, Collet B, Ingerslev E, Secombes CJ, Lorenzen N, Ellis AE (2003) DNA vaccination against viral haemorrhagic septicaemia (VHS) in rainbow trout: size, dose, route of injection and duration of protection - early protection correlates with Mx expression. Fish Shellfish Immunol 15:39-50

26. Purcell MK, Laing KJ, Winton JR (2012) Immunity to fish rhabdoviruses. Viruses 4:140-166

27. Castro R, Martínez-Alonso S, Fischer U, Haro NÁ, Soto-Lampe V, Wang T, Secombes CJ, Lorenzen N, Lorenzen E, Tafalla C (2014) DNA vaccination against a fish rhabdovirus promotes an early chemokine-related recruitment of B cells to the muscle. Vaccine 32:1160-1168

28. LaPatra SE, Corbeil S, Jones GR, Shewmaker WD, Kurath G (2000) The dose-dependent effect on protection and humoral response to a DNA vaccine against IHN virus in subyearling rainbow trout. J Aquat Anim Health 12:181-188

29. Somamoto T, Nakanishi T, Okamoto N (2002) Role of specific cell-mediated cytotoxicity in protecting fish from viral infections. Virology 297:120-127

30. Somamoto T, Koppang EO, Fischer U (2014) Antiviral functions of CD8(+) cytotoxic T cells in teleost fish. Dev Comp Immunol 43:197-204

31. Lorenzen N, Lorenzen E, Einer-Jensen K, LaPatra SE (2002) Immunity induced shortly after DNA vaccination of rainbow trout against rhabdoviruses protects against heterologous virus but not against bacterial pathogens. Dev Comp Immunol 26:173-179

32. Caipang CM, Hirono I, Aoki T (2003) In vitro inhibition of fish rhabdoviruses by Japanese flounder, Paralichthys olivaceus Mx. Virology 317:373-382

33. Haller O, Kochs $G$ (2002) Interferon-induced $m x$ proteins: dynamin-like GTPases with antiviral activity. Traffic 3:710-717
34. Samuel CE (2001) Antiviral actions of interferons. Clin Microbiol Rev 14:778-809

35. Guo J, Hui DJ, Merrick WC, Sen GC (2000) A new pathway of translational regulation mediated by eukaryotic initiation factor 3. EMBO J 19:6891-6899

36. Langevin C, van der Aa LM, Houel A, Torhy C, Briolat V, Lunazzi A, Harmache A, Bremont M, Levraud JP, Boudinot P (2013) Zebrafish ISG15 exerts a strong antiviral activity against RNA and DNA viruses and regulates the interferon response. J Virol 87:10025-10036

37. Purcell MK, Nichols KM, Winton JR, Kurath G, Thorgaard GH, Wheeler P, Hansen JD, Herwig RP, Park LK (2006) Comprehensive gene expression profiling following DNA vaccination of rainbow trout against infectious hematopoietic necrosis virus. Mol Immunol 43:2089-2106

38. Akira S (2011) Innate immunity and adjuvants. Philos Trans R Soc Lond B Biol Sci 366:2748-2755

39. Langevin C, Aleksejeva E, Passoni G, Palha N, Levraud JP, Boudinot P (2013) The antiviral innate immune response in fish: evolution and conservation of the IFN system. J Mol Biol 425:4904-4920

40. Stevenson FK, Ottensmeier CH, Rice J (2010) DNA vaccines against cancer come of age. Curr Opin Immunol 22:264-270

41. Coban C, Ishii KJ, Gursel M, Klinman DM, Kumar N (2005) Effect of plasmid backbone modification by different human $\mathrm{CpG}$ motifs on the immunogenicity of DNA vaccine vectors. $\mathrm{J}$ Leukoc Biol 78:647-655

42. Coban C, Kobiyama K, Aoshi T, Takeshita F, Horii T, Akira S, Ishii KJ (2011) Novel strategies to improve DNA vaccine immunogenicity. Curr Gene Ther 11:479-484

43. Hølvold LB, Myhr AI, Dalmo RA (2014) Strategies and hurdles using DNA vaccines to fish. Vet Res 45:21

44. Lemaitre B, Nicolas E, Michaut L, Reichhart JM, Hoffmann JA (1996) The dorsoventral regulatory gene cassette spätzle/Toll/ cactus controls the potent antifungal response in Drosophila adults. Cell 86:973-983

45. Iwasaki A, Medzhitov R (2004) Toll-like receptor control of the adaptive immune responses. Nat Immunol 5:987-995

46. Akira S, Uematsu S, Takeuchi O (2006) Pathogen recognition and innate immunity. Cell 124:783-801

47. Matsushima N, Tanaka T, Enkhbayar P, Mikami T, Taga M, Yamada K, Kuroki Y (2007) Comparative sequence analysis of leucine-rich repeats (LRRs) within vertebrate toll-like receptors. BMC Genom 8:124

48. Oshiumi H, Tsujita T, Shida K, Matsumoto M, Ikeo K, Seya T (2003) Prediction of the prototype of the human Toll-like receptor gene family from the pufferfish, Fugu rubripes, genome. Immunogenetics 54:791-800

49. Jault C, Pichon L, Chluba J (2004) Toll-like receptor gene family and TIR-domain adapters in Danio rerio. Mol Immunol 40:759-771

50. Takano T, Hwang SD, Kondo H, Hirono I, Aoki T, Sano M (2010) Evidence of molecular toll-like receptor mechanisms in teleosts. Fish Pathol 45:1-16

51. Strandskog G, Skjaeveland I, Ellingsen T, Jørgensen JB (2008) Double-stranded RNA- and CpG DNA-induced immune responses in Atlantic salmon: comparison and synergies. Vaccine 26:4704-4715

52. Matsuo A, Oshiumi H, Tsujita T, Mitani H, Kasai H, Yoshimizu M, Matsumoto M, Seya T (2008) Teleost TLR22 recognizes RNA duplex to induce IFN and protect cells from birnaviruses. J Immunol 181:3474-3485

53. Diebold SS, Kaisho T, Hemmi H, Akira S, Reis e Sousa C (2004) Innate antiviral responses by means of TLR7-mediated recognition of single-stranded RNA. Science 303:1529-1531

54. Heil F, Hemmi H, Hochrein H, Ampenberger F, Kirschning C, Akira S, Lipford G, Wagner H, Bauer S (2004) Species-specific 
recognition of single-stranded RNA via toll-like receptor 7 and 8. Science 303:1526-1529

55. Hemmi H, Takeuchi O, Sato S, Yamamoto M, Kaisho T, Sanjo H, Kawai T, Hoshino K, Takeda K, Akira S (2004) The roles of two I $\mathrm{B}$ kinase-related kinases in lipopolysaccharide and double stranded RNA signaling and viral infection. J Exp Med 199:1641-1650

56. Purcell MK, Smith KD, Hood L, Winton JR, Roach JC (2006) Conservation of Toll-like receptor signaling pathways in teleost fish. Comp Biochem Physiol Part D Genomics Proteomics $1: 77-88$

57. Kileng $\varnothing$, Albuquerque A, Robertsen B (2008) Induction of interferon system genes in Atlantic salmon by the imidazoquinoline S-27609, a ligand for Toll-like receptor 7. Fish Shellfish Immunol 24:514-522

58. Sun B, Robertsen B, Wang Z, Liu B (2009) Identification of an Atlantic salmon IFN multigene cluster encoding three IFN subtypes with very different expression properties. Dev Comp Immunol 33:547-558

59. Takano T, Kondo H, Hirono I, Endo M, Saito-Taki T, Aoki T (2007) Molecular cloning and characterization of Toll-like receptor 9 in Japanese flounder, Paralichthys olivaceus. Mol Immunol 44:1845-1853

60. Zhou ZX, Zhang J, Sun L (2014) C7: a CpG oligodeoxynucleotide that induces protective immune response against megalocytivirus in Japanese flounder (Paralichthys olivaceus) via Toll-like receptor 9-mediated signaling pathway. Dev Comp Immunol 44:124-132

61. Jørgensen JB, Johansen LH, Steiro K, Johansen A (2003) CpG DNA induces protective antiviral immune responses in Atlantic salmon (Salmo salar L.). J Virol 77:11471-11479

62. Pedersen GM, Johansen A, Olsen RL, Jørgensen JB (2006) Stimulation of type I IFN activity in Atlantic salmon (Salmo salar L.) leukocytes: synergistic effects of cationic proteins and CpG ODN. Fish Shellfish Immunol 20:503-518

63. Roach JC, Glusman G, Rowen L, Kaur A, Purcell MK, Smith KD, Hood LE, Aderem A (2005) The evolution of vertebrate Toll-like receptors. Proc Natl Acad Sci USA 102:9577-9582

64. Brownlie R, Zhu J, Allan B, Mutwiri GK, Babiuk LA, Potter A, Griebel P (2009) Chicken TLR21 acts as a functional homologue to mammalian TLR9 in the recognition of CpG oligodeoxynucleotides. Mol Immunol 46:3163-3170

65. Aoki T, Hikima J, Hwang SD, Jung TS (2013) Innate immunity of finfish: primordial conservation and function of viral RNA sensors in teleosts. Fish Shellfish Immunol 35:1689-1702

66. Yeh DW, Liu YL, Lo YC, Yuh CH, Yu GY, Lo JF, Luo Y, Xiang R, Chuang TH (2013) Toll-like receptor 9 and 21 have different ligand recognition profiles and cooperatively mediate activity of CpG-oligodeoxynucleotides in zebrafish. Proc Natl Acad Sci USA 110:20711-20716

67. Zhang YB, Gui JF (2012) Molecular regulation of interferon antiviral response in fish. Dev Comp Immunol 38:193-202

68. Zou J, Chang M, Nie P, Secombes CJ (2009) Origin and evolution of the RIG-I like RNA helicase gene family. BMC Evol Biol 9:85

69. Ohtani M, Hikima J, Kondo H, Hirono I, Jung TS, Aoki T (2010) Evolutional conservation of molecular structure and antiviral function of a viral RNA receptor, LGP2, in Japanese flounder, Paralichthys olivaceus. J Immunol 185:7507-7517

70. Ohtani M, Hikima J, Kondo H, Hirono I, Jung TS, Aoki T (2011) Characterization and antiviral function of a cytosolic sensor gene, MDA5, in Japanese flounder, Paralichthys olivaceus. Dev Comp Immunol 35:554-562

71. Rajendran KV, Zhang J, Liu S, Peatman E, Kucuktas H, Wang X, Liu H, Wood T, Terhune J, Liu Z (2012) Pathogen recognition receptors in channel catfish: II. Identification, phylogeny and expression of retinoic acid-inducible gene I (RIG-I)-like receptors (RLRs). Dev Comp Immunol 37:381-389

72. Yang C, Su J, Huang T, Zhang R, Peng L (2011) Identification of a retinoic acid-inducible gene I from grass carp (Ctenopharyngodon idella) and expression analysis in vivo and in vitro. Fish Shellfish Immunol 30:936-943

73. Feng H, Liu H, Kong R, Wang L, Wang Y, Hu W, Guo Q (2011) Expression profiles of carp IRF-3/-7 correlate with the upregulation of RIG-I/MAVS/TRAF3/TBK1, four pivotal molecules in RIG-I signaling pathway. Fish Shellfish Immunol 30:1159-1169

74. Skjesol A, Skjæveland I, Elnæs M, Timmerhaus G, Fredriksen BN, Jørgensen SM, Krasnov A, Jørgensen JB (2011) IPNV with high and low virulence: host immune responses and viral mutations during infection. Virol J 8:396

75. Su J, Huang T, Dong J, Heng J, Zhang R, Peng L (2010) Molecular cloning and immune responsive expression of MDA5 gene, a pivotal member of the RLR gene family from grass carp Ctenopharyngodon idella. Fish Shellfish Immunol 28:712-718

76. Huang T, Su J, Heng J, Dong J, Zhang R, Zhu H (2010) Identification and expression profiling analysis of grass carp Ctenopharyngodon idella LGP2 cDNA. Fish Shellfish Immunol 29:349-355

77. Jensen I, Seppola M, Steiro K, Sandaker E, Mennen S, Sommer AI (2009) Susceptibility of Atlantic cod Gadus morhua juveniles to different routes of experimental challenge with infectious pancreatic necrosis virus (IPNV). Dis Aquat Organ 85:105-113

78. Rise ML, Hall J, Rise M, Hori T, Gamperl A, Kimball J, Hubert S, Bowman S, Johnson SC (2008) Functional genomic analysis of the response of Atlantic cod (Gadus morhua) spleen to the viral mimic polyriboinosinic polyribocytidylic acid (pIC). Dev Comp Immunol 32:916-931

79. Rise ML, Hall JR, Rise M, Hori TS, Browne MJ, Gamperl AK, Hubert S, Kimball J, Bowman S, Johnson SC (2010) Impact of asymptomatic nodavirus carrier state and intraperitoneal viral mimic injection on brain transcript expression in Atlantic cod (Gadus morhua). Physiol Genomics 42:266-280

80. Hornung V, Ellegast J, Kim S, Brzózka K, Jung A, Kato H, Poeck H, Akira S, Conzelmann KK, Schlee M, Endres S, Hartmann G (2006) 5'-Triphosphate RNA is the ligand for RIG-I. Science 314:994-997

81. Pichlmair A, Schulz O, Tan CP, Näslund TI, Liljeström P, Weber F, Reis e Sousa C (2006) RIG-I-mediated antiviral responses to single-stranded RNA bearing $5^{\prime}$-phosphates. Science 314:997-1001

82. Kato H, Takeuchi O, Mikamo-Satoh E, Hirai R, Kawai T, Matsushita K, Hiiragi A, Dermody TS, Fujita T, Akira S (2008) Length-dependent recognition of double-stranded ribonucleic acids by retinoic acid-inducible gene-I and melanoma differentiation-associated gene 5. J Exp Med 205:1601-1610

83. Yoneyama M, Kikuchi M, Natsukawa T, Shinobu N, Imaizumi T, Miyagishi M, Taira K, Akira S, Fujita T (2004) The RNA helicase RIG-I has an essential function in double-stranded RNAinduced innate antiviral responses. Nat Immunol 5:730-737

84. Kato H, Takeuchi O, Sato S, Yoneyama M, Yamamoto M, Matsui K, Uematsu S, Jung A, Kawai T, Ishii KJ, Yamaguchi O, Otsu K, Tsujimura T, Koh CS, Reis e Sousa C, Matsuura Y, Fujita T, Akira S (2006) Differential roles of MDA5 and RIG-I helicases in the recognition of RNA viruses. Nature 441:101-105

85. Li X, Ranjith-Kumar CT, Brooks MT, Dharmaiah S, Herr AB, Kao C, Li P (2009) The RIG-I-like receptor LGP2 recognizes the termini of double-stranded RNA. J Biol Chem 284:13881-13891

86. Chen L, Su J, Yang C, Peng L, Wan Q, Wang L (2012) Functional characterizations of RIG-I to GCRV and viral/bacterial 
PAMPs in grass carp Ctenopharyngodon idella. PLoS ONE 7:e42182

87. Sun F, Zhang YB, Jiang J, Wang B, Chen C, Zhang J, Gui JF (2014) Gig1, a novel antiviral effector involved in fish interferon response. Virology 448:322-332

88. Li S, Sun F, Zhang YB, Gui JF, Zhang QY (2012) Identification of DreI as an antiviral factor regulated by RLR signaling pathway. PLoS ONE 7:e32427

89. Sullivan C, Postlethwait JH, Lage CR, Millard PJ, Kim CH (2007) Evidence for evolving Toll-IL-1 receptor-containing adaptor molecule function in vertebrates. J Immunol 178:4517-4527

90. Fan S, Chen S, Liu Y, Lin Y, Liu H, Guo L, Lin B, Huang S, Xu A (2008) Zebrafish TRIF, a Golgi-localized protein, participates in IFN induction and NF- $\mathrm{B}$ activation. J Immunol 180:5373-5383

91. Kawai T, Akira S (2007) TLR signaling. Semin Immunol 19:24-32

92. Ishii KJ, Kawagoe T, Koyama S, Matsui K, Kumar H, Kawai T, Uematsu S, Takeuchi O, Takeshita F, Coban C, Akira S (2008) TANK-binding kinase- 1 delineates innate and adaptive immune responses to DNA vaccines. Nature 451:725-729

93. Fullam A, Schröder M (2013) DExD/H-box RNA helicases as mediators of anti-viral innate immunity and essential host factors for viral replication. Biochim Biophys Acta 1829:854-865

94. Keating SE, Baran M, Bowie AG (2011) Cytosolic DNA sensors regulating type I interferon induction. Trends Immunol 32:574-581

95. Takeuchi O, Akira S (2010) Pattern recognition receptors and inflammation. Cell 140:805-820

96. Thompson AJV, Locarnini SA (2007) Toll-like receptors, RIGI-like RNA helicases and the antiviral innate immune response. Immunol Cell Biol 85:435-445

97. Fitzgerald KA, McWhirter SM, Faia KL, Rowe DC, Latz E, Golenbock DT, Coyle AJ, Liao SM, Maniatis T (2003) IKKe and TBK1 are essential components of the IRF3 signaling pathway. Nat Immunol 4:491-496

98. Sharma S, tenOever BR, Grandvaux N, Zhou GP, Lin R, Hiscott J (2003) Triggering the interferon antiviral response through an IKK-related pathway. Science 300:1148-1151

99. Pomerantz JL, Baltimore D (1999) NF-кB activation by a signaling complex containing TRAF2, TANK and TBK1, a novel IKK-related kinase. EMBO J 18:6694-6704

100. McWhirter SM, Fitzgerald KA, Rosains J, Rowe DC, Golenbock DT, Maniatis T (2004) IFN-regulatory factor 3-dependent gene expression is defective in Tbk1-deficient mouse embryonic fibroblasts. Proc Natl Acad Sci USA 101:233-238

101. Mori M, Yoneyama M, Ito T, Takahashi K, Inagaki F, Fujita T (2004) Identification of Ser-386 of interferon regulatory factor 3 as critical target for inducible phosphorylation that determines activation. J Biol Chem 279:9698-9702

102. Caillaud A, Hovanessian AG, Levy DE, Marié IJ (2005) Regulatory serine residues mediate phosphorylation-dependent and phosphorylation-independent activation of interferon regulatory factor 7. J Biol Chem 280:17671-17677

103. Lin R, Heylbroeck C, Pitha PM, Hiscott J (1998) Virus-dependent phosphorylation of the IRF-3 transcription factor regulates nuclear translocation, transactivation potential, and proteasomemediated degradation. Mol Cell Biol 18:2986-2996

104. Sato M, Suemori H, Hata N, Asagiri M, Ogasawara K, Nakao K, Nakaya T, Katsuki M, Noguchi S, Tanaka N, Taniguchi T (2000) Distinct and essential roles of transcription factors IRF-3 and IRF-7 in response to viruses for IFN- $\alpha / \beta$ gene induction. Immunity 13:539-548

105. Shen RR, Hahn WC (2011) Emerging roles for the non-canonical IKKs in cancer. Oncogene 30:631-641
106. Shimada T, Kawai T, Takeda K, Matsumoto M, Inoue J, Tatsumi Y, Kanamaru A, Akira S (1999) IKK-i, a novel lipopolysaccharide-inducible kinase that is related to IкB kinases. Int Immunol 11:1357-1362

107. Honda K, Yanai H, Negishi H, Asagiri M, Sato M, Mizutani T, Shimada N, Ohba Y, Takaoka A, Yoshida N, Taniguchi T (2005) IRF-7 is the master regulator of type-I interferon-dependent immune responses. Nature 434:772-777

108. Gravel SP, Servant MJ (2005) Roles of an IкB kinase-related pathway in human cytomegalovirus-infected vascular smooth muscle cells: a molecular link in pathogen-induced proatherosclerotic conditions. J Biol Chem 280:7477-7486

109. Bibeau-Poirier A, Gravel SP, Clément JF, Rolland S, Rodier G, Coulombe P, Hiscott J, Grandvaux N, Meloche S, Servant MJ (2006) Involvement of the IKB kinase (IKK)-related kinases tank-binding kinase $1 / \mathrm{IKKi}$ and cullin-based ubiquitin ligases in IFN regulatory factor-3 degradation. J Immunol 177:5059-5067

110. Chi H, Zhang Z, Bøgwald J, Zhan W, Dalmo RA (2011) Cloning, expression analysis and promoter structure of TBK1 (TANK-binding kinase 1) in Atlantic cod (Gadus morhua L.). Fish Shellfish Immunol 30:1055-1063

111. Sun F, Zhang YB, Liu TK, Shi J, Wang B, Gui JF (2011) Fish MITA serves as a mediator for distinct fish IFN gene activation dependent on IRF3 or IRF7. J Immunol 187:2531e9

112. Biacchesi S, Mérour E, Lamoureux A, Bernard J, Brémont M (2012) Both STING and MAVS fish orthologs contribute to the induction of interferon mediated by RIG-I. PLoS One 7:e47737

113. Ratsimandresy RA, Dorfleutner A, Stehlik C (2013) An update on PYRIN domain-containing pattern recognition receptors: from immunity to pathology. Front Immunol 4:440

114. Schröder M, Baran M, Bowie AG (2008) Viral targeting of DEAD box protein 3 reveals its role in TBK1/IKKepsilonmediated IRF activation. EMBO J 27:2147-2157

115. Zhang Z, Yuan B, Bao M, Lu N, Kim T, Liu YJ (2011) The helicase DDX41 senses intracellular DNA mediated by the adaptor STING in dendritic cells. Nat Immunol 12:959-965

116. Parvatiyar K, Zhang Z, Teles RM, Ouyang S, Jiang Y, Iyer SS, Zaver SA, Schenk M, Zeng S, Zhong W, Liu ZJ, Modlin RL, Liu YJ, Cheng G (2012) The helicase DDX41 recognizes the bacterial secondary messengers cyclic di-GMP and cyclic di-AMP to activate a type I interferon immune response. Nat Immunol 13:1155-1161

117. Zhang Z, Bao M, Lu N, Weng L, Yuan B, Liu YJ (2013) The E3 ubiquitin ligase TRIM21 negatively regulates the innate immune response to intracellular double-stranded DNA. Nat Immunol 14:172-178

118. Sommerset I, Skern R, Biering E, Bleie H, Fiksdal IU, Grove S, Nerland AH (2005) Protection against Atlantic halibut nodavirus in turbot is induced by recombinant capsid protein vaccination but not following DNA vaccination. Fish Shellfish Immunol 18:13-29

119. Mikalsen AB, Torgersen J, Aleström P, Hellemann AL, Koppang EO, Rimstad E (2004) Protection of Atlantic salmon Salmo salar against infectious pancreatic necrosis after DNA vaccination. Dis Aquat Organ 60:11-20

120. Mikalsen AB, Sindre H, Torgersen J, Rimstad E (2005) Protective effects of a DNA vaccine expressing the infectious salmon anemia virus hemagglutinin-esterase in Atlantic salmon. Vaccine 23:4895-4905

121. Emmenegger EJ, Kurath G (2008) DNA vaccine protects ornamental koi (Cyprinus carpio koi) against North American spring viremia of carp virus. Vaccine 26:6415-6421

122. Boudinot P, Blanco M, de Kinkelin P, Benmansour A (1998) Combined DNA immunization with the glycoprotein gene of viral hemorrhagic septicemia virus and infectious hematopoietic necrosis virus induces double-specific protective immunity and nonspecific response in rainbow trout. Virology 249:297-306 
123. Einer-Jensen K, Delgado L, Lorenzen E, Bovo G, Evensen $\emptyset$, Lapatra S, Lorenzen N (2009) Dual DNA vaccination of rainbow trout (Oncorhynchus mykiss) against two different rhabdoviruses, VHSV and IHNV, induces specific divalent protection. Vaccine 27:1248-1253

124. Nusbaum KE, Smith BF, DeInnocentes P, Bird RC (2002) Protective immunity induced by DNA vaccination of channel catfish with early and late transcripts of the channel catfish herpesvirus (IHV-1). Vet Immunol Immunopathol 84:151-168

125. Tian J, Yu J (2011) Poly (lactic-co-glycolic acid) nanoparticles as candidate DNA vaccine carrier for oral immunization of Japanese flounder (Paralichthys olivaceus) against lymphocystis disease virus. Fish Shellfish Immunol 30:109-117

126. Zhou JX, Wang H, Li XW, Zhu X, Lu WL, Zhang DM (2014) Construction of KHV-CJ ORF25 DNA vaccine and immune challenge test. J Fish Dis 37:319-325

127. Vazquez-Juarez RC, Gomez-Chiarri M, Barrera-Saldaña $H$, Hernandez-Saavedra N, Dumas S, Ascencio F (2005) Evaluation of DNA vaccination of spotted sand bass (Paralabrax maculatofasciatus) with two major outer-membrane proteinencoding genes from Aeromonas veronii. Fish Shellfish Immunol 19:153-163

128. Plant KP, LaPatra SE, Cain KD (2009) Vaccination of rainbow trout, Oncorhynchus mykiss (Walbaum), with recombinant and DNA vaccines produced to Flavobacterium psychrophilum heat shock proteins 60 and 70. J Fish Dis 32:521-534

129. Huang LY, Wang KY, Xiao D, Chen DF, Geng Y, Wang J, He Y, Wang EL, Huang JL, Xiao GY (2014) Safety and immunogenicity of an oral DNA vaccine encoding Sip of Streptococcus agalactiae from Nile tilapia Oreochromis niloticus delivered by live attenuated Salmonella typhimurium. Fish Shellfish Immunol 38:34-41

130. Sun Y, Hu YH, Liu CS, Sun L (2010) Construction and analysis of an experimental Streptococcus iniae DNA vaccine. Vaccine 28:3905-3912

131. Cai SH, Lu YS, Jian JC, Wang B, Huang YC, Tang JF, Ding Y, Wu ZH (2013) Protection against Vibrio alginolyticus in crimson snapper Lutjanus erythropterus immunized with a DNA vaccine containing the ompW gene. Dis Aquat Organ 106:39-47

132. Kumar SR, Parameswaran V, Ahmed VP, Musthaq SS, Hameed AS (2007) Protective efficiency of DNA vaccination in Asian seabass (Lates calcarifer) against Vibrio anguillarum. Fish Shellfish Immunol 23:316-326

133. Hu YH, Sun L (2011) A bivalent Vibrio harveyi DNA vaccine induces strong protection in Japanese flounder (Paralichthys olivaceus). Vaccine 29:4328-4333

134. Sun Y, Zhang M, Liu CS, Qiu R, Sun L (2012) A divalent DNA vaccine based on Sia10 and OmpU induces cross protection against Streptococcus iniae and Vibrio anguillarum in Japanese flounder. Fish Shellfish Immunol 32:1216-1222

135. Hwang SD, Ohtani M, Hikima J, Jung TS, Kondo H, Hirono I, Aoki T (2012) Molecular cloning and characterization of Tolllike receptor 3 in Japanese flounder, Paralichthys olivaceus. Dev Comp Immunol 37:87-96

136. Su J, Zhu Z, Wang Y, Zou J, Hu W (2008) Toll-like receptor 3 regulates $\mathrm{Mx}$ expression in rare minnow Gobiocypris rarus after viral infection. Immunogenetics 60:195-205

137. Lee PT, Zou J, Holland JW, Martin SA, Kanellos T, Secombes CJ (2013) Identification and characterization of TLR7, TLR8a2, TLR8b1 and TLR8b2 genes in Atlantic salmon (Salmo salar). Dev Comp Immunol 41:295-305

138. Svingerud T, Solstad T, Sun B, Nyrud ML, Kileng $\varnothing$, GreinerTollersrud L, Robertsen B (2012) Atlantic salmon type I IFN subtypes show differences in antiviral activity and cell-dependent expression: evidence for high IFNb/IFNc-producing cells in fish lymphoid tissues. J Immunol 189:5912-5923

139. Palti Y, Gahr SA, Purcell MK, Hadidi S, Rexroad CE 3rd, Wiens GD (2010) Identification, characterization and genetic mapping of TLR7, TLR8a1 and TLR8a2 genes in rainbow trout (Oncorhynchus mykiss). Dev Comp Immunol 34:219-233

140. Skjaeveland I, Iliev DB, Zou J, Jørgensen T, Jørgensen JB (2008) A TLR9 homolog that is up-regulated by IFN- $\gamma$ in Atlantic salmon (Salmo salar). Dev Comp Immunol 32:603-607

141. Iliev DB, Skjæveland I, Jørgensen JB (2013) CpG oligonucleotides bind TLR9 and RRM-containing proteins in Atlantic salmon (Salmo salar). BMC Immunol 14:12

142. Biacchesi S, LeBerre M, Lamoureux A, Louise Y, Lauret E, Boudinot P, Brémont M (2009) Mitochondrial antiviral signaling protein plays a major role in induction of the fish innate immune response against RNA and DNA viruses. J Virol 83:7815-7827

143. Zou PF, Chang MX, Xue NN, Liu XQ, Li JH, Fu JP, Chen SN, Nie P (2014) Melanoma differentiation-associated gene 5 in zebrafish provoking higher interferon-promoter activity through signalling enhancing of its shorter splicing variant. Immunology 141:192-202

144. Hikima J, Yi MK, Ohtani M, Jung CY, Kim YK, Mun JY, Kim YR, Takeyama H, Aoki T, Jung TS (2012) LGP2 expression is enhanced by interferon regulatory factor 3 in olive flounder Paralichthys olivaceus. PLoS One 7:e51522

145. Chang M, Collet B, Nie P, Lester K, Campbell S, Secombes CJ, Zou J (2011) Expression and functional characterization of the RIG-I-like receptors MDA5 and LGP2 in rainbow trout (Oncorhynchus mykiss). J Virol 85:8403-8412 